


\title{
George Steiner's Metaphors for Translation: A Critical Commentary
}

\author{
Brian O'KEEFFE \\ Barnard College, New York
}

\begin{abstract}
George Steiner's After Babel contains many riches, and many of these can be found in the chapter "The Hermeneutic Motion". But that chapter has its challenges and vexing provocations, and it therefore merits critical commentary. At issue, I argue, is the problematic elaboration of various metaphors for translation and a certain laxity in argument that is covered over by the fineness of Steiner's writing style. The purpose of this essay is to offer such a commentary, and to do so by making two further propositions: firstly, that this chapter in After Babel stands to gain if it's read alongside his 1989 book Real Presences; secondly, that it can be elucidated by way of a thinker who, despite Steiner's own reservations, is quite pertinent to the matters addressed in "The Hermeneutic Motion", namely Jacques Derrida.
\end{abstract}

Keywords: Translation, Metaphor, Eating, Fidelity, Echo.

\section{Introduction}

For me, reading George Steiner's After Babel (1975/1992) engages a four-fold sequence of activity. I begin with respect for its scholarship. Then I make my incursions into Steiner's text, raid it for its 
insights and take those pillaged perceptions into my own work. But After Babel is plentiful in the food for thought it offers, and so I feel overladen - like eating foie gras, Steiner's fare is rich. Having taken so much, I need to register my debt to Steiner and After Babel. The purpose of this essay is accordingly to acknowledge his magnificent effort on behalf of translation studies by paying careful attention to After Babel, an attention that will be critical in some respects, but conducted, I trust, in the spirit of what, in Real Presences (1989), Steiner describes as cortesia.

In the preface to the 1992 re-print, Steiner complains that " $A f-$ ter Babel has been drawn upon and pilfered, often without acknowledgement" (Steiner 1992: xi). Referring to a work of translation studies he doesn't name, Steiner wonders why After Babelis invoked only in a footnote, even as that note praises it highly. The unnamed work is Andrew Benjamin's Translation and the Nature of Philosophy (1989). The footnote reads:

Probably the most sustained and significant work on translation is G. Steiner, After Babel [...]. His scholarship and linguistic ability cannot really be matched. I have been content therefore to offer a philosophical reflection on translation. If the argument I have advanced is followed this is a reflection on philosophy itself. (Benjamin 1989: 181)

On the one hand, After Babel crowded out the field. On the other, it didn't because there isn't a proper philosophical reflection on translation (or a reflection on translation's status in philosophy). One imagines Steiner disliking Benjamin's remark, given Steiner's zeal to say everything about translation, including what philosophy says about it. But besides what Steiner's book doesn't provide, one factor explaining After Babels neglect might well concern what it does provide: vast scholarship that outstrips the capacities of most readers to gain adequate purchase on it. After Babel isn't just a work of literary criticism, or literary history, nor else just a work of linguistic theory. It's much else besides.

Too much, perhaps. Was After Babel too good for its own good? Was Steiner too deft in deploying his scholarship? Did Steiner write too well? One feels uncouth criticising Steiner's writing, but sometimes his eloquence tips over into magniloquence. Some- 
times one baulks at his erudite superfluities. James Wood (1999: 155), speaking generally of Steiner's work, refers to its "imprecisions and melodramas", citing Nabokov's complaint that one of Steiner's essays was "built on solid abstractions and opaque generalisations" (ibid.). Perhaps that's not true of After Babel, but in my view, there are occasions where the point becomes elusive, and the thought is left un-clinched as Steiner's elegant prose runs ahead of itself, hastens to the next image, reference, metaphor or analogy.

In respect of metaphors and analogies, there is, in After Babel, an oversupply of statements declaring what translation is like: shellsmashing, eating something, and also mining excavations stripping seams of ore-translation scoops into the original text, and hauls its linguistic quarry away. Some will dislike the welter of metaphors, similes and analogies. Some will feel that Steiner's style has a powerful, too-powerful rhetorical effect - that of persuading, or seducing us into thinking that, indeed so, translation resembles such things. Others will remain unpersuaded, and prefer other images for translation's activities.

Adopting a 'take it or leave it' attitude to Steiner's images (or anyone else's) doesn't obviate the difficulty of representing 'translation' itself. Is it inevitable that we are always referred to metaphors in order to represent 'it'? Or are we constantly referred to the definition of 'metaphor' as such (if one can dare put it like that)? Steiner, for his part, is unabashed about his own metaphorics, and (this might be Benjamin's point) refrains from what one might call an 'abyssal' (or specular) reflection as regards stabilising the identity of translation, one which ends up with philosophy's age-old anxieties concerning mimesis, representation, metaphor, and literature-we know this from Plato's Republic. To that list of anxiety-producing issues for philosophy, we might indeed wish to add 'translation' as well.

Yet if perhaps there isn't enough philosophy in After Babel (the complaint is inane, I admit-it's like objecting that Shakespeare wrote Hamlet but didn't write the Phenomenology of Spirit instead), Steiner does remark upon developments in phenomenology, for instance. Mention is made of Schleiermacher. Above all, Steiner con- 
siders two developments in the $20^{\text {th }}$ century to be highly significant: the belated 'discovery' of Walter Benjamin's essay "The Task of the Translator" (1923/1996) and the boost to hermeneutic enquiry given by Heidegger and Gadamer.

Benjamin, Heidegger and Gadamer are the touch-stones for a renewed approach to translation theory. But consider "The Task of the Translator" in relation to Gadamerian hermeneutics: Gadamer has things to say about translation but never, as far as I know, refers to Benjamin's essay. Why? Ricœur says more, but arguably says too little, compared to the interest in Benjamin's text shown by a very different philosopher, namely Derrida. Why is "The Task of the Translator" amenable to deconstruction but indigestible for hermeneutics? As for Steiner, while he proposes a hermeneutic approach to translation, there's more Benjamin in Steiner than one generally finds in hermeneutics, and since I will, to Steiner's displeasure (and perhaps scholars of the hermeneutic persuasion), shortly find occasion to adduce Derrida, I will be doing so in order to show that there's more Derrida in Steiner than the author of After Babel might wish to acknowledge, or at least more of Derrida that is relevant to an assessment of After Babel than appears at first sight.

\section{Trust in Meaning, or: The Translator's Hospitality}

How to begin? Begin by trusting in the sense of a text. Admittedly, "the trust can never be final", Steiner says. "It is betrayed, trivially, by nonsense" (Steiner 1975/1992: 312) like poésie concrète, nonsense rhymes and glossolalia. But, assuming such cases can be limited to the merely 'trivial', the first motion of translation is this:

There is initiative trust, an investment of belief, underwritten by previous experience but epistemologically exposed and psychologically hazardous, in the meaningfulness, in the 'seriousness' of the facing or, strictly speaking, adverse text. We venture a leap: we grant ab initio that there is 'something there' to be understood, that the transfer will not be void. (Ibid.: 312)

Presently I will want to query that epistemological exposure and those psychological hazards, since Steiner doesn't describe them, 
nor what causes them. It's enough to say, for now, that translators trustingly assume that texts mean to mean, and that such trust will be rewarded by the texts' proffering of meaning.

That trust is informed by the massive evidence that the world itself is meaningful: "The translator must gamble on the coherence, on the symbolic plenitude of the world" (Steiner 1975/1992: 313). And if "all understanding, and the demonstrative statement of understanding which is translation, starts with an act of trust" (ibid.: 312), then we can say that no understanding, and the demonstrative statement of understanding which is translation, starts with an act of suspicion, since what cannot be suspected is that the world isn't coherent, or symbolically plenished by meaning itself. Nietzsche, or Derrida, might disagree. But for Steiner, the translator invests in "phenomenal assumptions about the coherence of the world, about the presence of meaning" (ibid.: 312). To mollify the ghosts of Nietzsche and Derrida, we might nevertheless look hard at "phenomenal" and the "presence of meaning". Trustingly does the translator come into the presence of meaning, making phenomenal assumptions (or safe bets) concerning worldly coherence. Steiner's translator resembles Husserl, desirous of phenomena and presences, and emphatically doesn't resemble Derrida, he for whom invocations of presence betray a 'metaphysics' whose underlying assumptions warrant deconstruction.

In any case, the translator begins with trust. But certain problems emerge. Steiner speaks of the "radical generosity of the translator ('I grant beforehand that there must be something there'), his trust in the 'other"' (Steiner 1975/1992: 312). But such generosity isn't really radical if the translator's trust is only ever betrayed by 'trivial' instances of nonsense. Steiner writes: "But the donation of trust remains ontologically spontaneous and anticipates proof' (ibid.: 313). How spontaneous can that gesture be if it profiles anticipation as well? Really radical generosity would give, or donate without expectation or anticipation of return, and refrain from specifying the form in which the text ought reward that trusthere, the form of proof. 
Perhaps I'm being captious. Perhaps one should regard matters more simply: Steiner's translator trusts texts, and, as a relation to texts (it's not an interpretive activity), that trust resembles Wayne Booth's 'befriending' model of reading, as described in The Company We Keep (1988). Booth significantly provides the back-cover blurb for Real Presences, and, on that score, it may be instructive to detour via Real Presences and seek similar models of textual trusting and befriending. And do so, moreover, while bearing in mind that Steiner has already told us that translators invest in "shenomenal assumptions about the coherence of the world, about the presence of meaning".

Reading, Steiner says in Real Presences, involves risk: coming before us might be a presence who will betray our trust:

The presence before us might be that of a mute (Beckett edges towards that grim jest), of a madman uttering gibberish, or, more disturbingly, of an intensely communicative persona whose idiom-linguistic, stylistic, hermetically-grounded—we simply cannot grasp. (Steiner 1989: 156)

What disconcerts Steiner is gibberish, idiomatic inaccessibility, and mutism. Silence is unwelcome, and, as we'll see, Steiner often describes reading and translation in terms of acoustic attunement and concinnity. Speaking of the 'endeavour' of trust in textual meaning, Steiner says that

There is in this endeavour, as deconstruction would immediately point out, an ultimately unprovable hope and presupposition of sense, a presumption that intelligibility is conceivable, and, indeed, realisable. Such a presupposition is always susceptible of refutation. (Steiner 1989: 156)

In After Babel, the translator's trust is conditioned by the expectation that texts will offer proof of their meaning. Here, that trust is both shadowed and informed by "unprovable hope", and thus can only be a presupposition, or else a hopeful, but always risky gamble. But why will deconstruction immediately point out that intelligibility is unprovable, that the wager on meaning might not prove to be a sure bet? Why is "such a presupposition always susceptible of refutation"? Derrida might remark that, once one declares that such a presupposition is always "susceptible of refutation," one cannot, as 
Steiner does in After Babel, restrict instances of nonsense to merely 'trivial' cases (recall Derrida's assessment of Austin and Searle).

One wishes Steiner had said more. The brevity of Steiner's remark conceals, or represses the entirety of the post-Saussurean and deconstructionist developments which, for better or for worse, inform current thinking on meaning, language and presence. But let's carry on 'beginning'. Readers now attune themselves to discrete words, delve into dictionaries to grasp the manifold meanings of words deployed by the text at hand. It's a matter of "lexical cortesia, the first step in philology [...], that which makes us dwellers in the great dictionaries" (Steiner 1989: 157). Steiner says:

Where the poem, where the verbal construct is concerned, the opening of the door, the practices of courtesy which this motion of trust comports, are those of lexical-grammatical-formal study. We strive to achieve the greatest possible degree of accurate audition. If the poem is speaking out of our own tongue, we seek to ascertain the historical, social, if need be local or dialectal, status of the poet's particular idiom. If the text is in a foreign language-and there is no more concentrated instance of 'otherness' and of its freedom of being than that of our encounters with languages not our own-we do our laboured best either to master that other speech or to accept the humbling trust of translation. (Steiner 1989: 156f.)

Lovely images of welcome, door openings, and courteous hosting. To welcome texts is to pay them the courtesy of deep study and "accurate audition". Lovely is the formulation "the humbling trust of translation". The following stage involves the text's grammar. Whence "the grammarian-reader" (Steiner 1989: 159), and the prescription that "one must be able to hear grammar made music" (ibid.: 161). Again, it's all about listening. A text's semantics next requires attention to context. Steiner, aware of the difficulties of establishing the perimeters of meaningful context, says "the circles of informing context spread concentrically to the unbounded" (ibid.: 163). Derrida would approve: the image of presumably seamless circles makes his point that no meaning can be determined out of context (there's no 'outside' the circle), but the line to which circles spread gives us Derrida's other point, namely that no context permits the saturation of meaning because the boundaries of context are, in fact, unbounded. 
Here, then, are Steiner's stages of reading. But everything begins with cortesia, with the welcome shown to texts by opening a door: "The movement towards reception and apprehension does embody an initial, fundamental act of trust. [...] But without the gamble on welcome, no door can be opened when freedom knocks" (Steiner 1989: 156). Steiner envisions the rendezvous of two freedoms: the text is free to offer or withhold itself, and the reader is free to receive the offering or refuse it. Explored here are freedoms, enacted here is cortesia: "Where freedoms meet, where the integral liberty of donation or withholding of the work of art encounters our own liberty of reception or refusal, cortesia, what I have called tact of heart, is of the essence" (ibid.: 155).

Steiner likens reading to the ethical response to the 'other'. But will readers accept that ethical obligations govern their activities? Steiner appeals to theology and speculative metaphysics: "Theology and speculative metaphysics engage the possibilities of meeting or of non-meeting with the 'other' in its transcendent guise" (Steiner 1989: 154). Moreover, "the numinous intimations which relate hospitality to religious feeling [...], the intuition that the true reception of a guest, of a known stranger in our place of being touches on transcendent obligations and opportunities" (Steiner 1989: 155). Are such transcendent obligations sufficiently transcendent that they also govern readers? Will readers sense those numinous intimations, experience religiosity as the text-as-other nears, comes hither as a well-nigh real presence?

Attitudes to this will vary-for some, this is fanciful. For others, the scenario Steiner describes is question-begging in any case. Steiner prefers xenodochy. But the trusting reader is surely emboldened to such trust since she already recognises that stranger-it's a "known stranger". Furthermore, when Steiner writes that "face to face with the presence of offered meaning, which we call a text [...], we seek to hear its language. As we would that of the elect stranger coming towards us" (Steiner 1989: 156), the stranger is "elect" and therefore neither wholly other, nor a complete stranger. And, "also here, the naïve analogy with the stranger's entrance, with the modulation, where it is possible, of 
stranger into guest, instructs us" (ibid.: 176). I'm not sure why the analogy suddenly becomes "naïve", but note "where it is possible" - a bland interpolation eliding the hermeneutical dilemma at issue. For Richard Kearney, the dilemma is this: before the host opens the door she doesn't know whether the 'other' will turn out to be a stranger, god, or monster. A “diacritical hermeneutics", Kearney (2003: 18) proposes, must intervene in order to assess whether to bar the door to a monster, or to open it in welcome of a visitor.

Levinas would insist, however, that the host's obligation to the other requires that no conditions be laid upon the possibility of welcome (and that welcome shouldn't necessarily be assessed in terms of 'possibility'). Making an unconditional gesture to the other entails welcoming monsters as much as gods or strangers, à nos risques et périls. This exposure to the other might occasion what Steiner describes as translators' trust that is nevertheless "epistemologically exposed and psychologically hazardous". But only if such exposures and hazards are verily acute, Levinas would say, can the otherness of the other be respected absolutely. Consider this, moreover: "That which comes to call on us - that idiom, we saw, connotes both spontaneous visitation and summons-will very often do so unbidden" (Steiner 1989: 179). Levinas would agree that the key moment of ethical hospitality occurs when one isn't expecting to be called, visited, and summoned. But Levinas would probably say that the other always arrives "unbidden", rather than "very often".

If one deems Steiner's scenario of ethical hospitality merely fanciful, these questions, which I raise by way of Kearney and Levinas, are irrelevant. Steiner, vis-à-vis these "mythologies of welcome" (Steiner 1989: 165), at least poses the question: "How does this simile of entrance translate into our actual aesthetic experience?" (ibid.: 177) Perhaps aesthetic experience becomes ethical experience and then becomes akin to religious experience. A communion, that is, with real presence. If we accept Steiner's "simile", then we may appreciate that " $[t]$ he philological space $[. .$.$] is that of the$ expectant, of the risks of trust taken in the decision to open a door" (ibid.: 177). Readers and translators are hosts. Reading and translation's first act involves ushering texts across thresholds. The act is 
different for translation, however, since the foreign text is now transposed into the host's language-whence what Derrida (1998: 78) describes as "the monolingualism of the host". But after that threshold-crossing, what happens next? What should happen is interpretive sensitivity: nothing should prompt us, in view of the textas-guest, "to strip it bare, to dissect it in some brutal rhetoric or hermeneutic of total penetration and subjection" (Steiner 1989: 176). The example he gives is Barthes's $S / Z$, adding “There are elements of like violence, though seemingly playful, in structuralism and deconstruction" (ibid.: 176). How to decide when play isn't play, but interpretive violence? Is total penetration the issue? Would partial violence be acceptable? Let's now attend to Steiner's own violence.

\section{Varieties of Violence}

"After trust comes aggression. The second move of the translator is incursive and extractive" (Steiner 1975/1992: 313). Moreover, "The translator invades, extracts, and brings home. The simile is that of the open-cast mine left an empty scar on the landscape" (ibid.: 314). Consider also that 'We 'break' a code: decipherment is dissective, leaving the shell smashed and the vital layers stripped" (ibid.: 314). Well, if, in Real Presences, structuralism and deconstruction's brutality is described as a stripping bare and as dissection (cf. Steiner 1989: 176), are Steiner's translators, since they apparently perform the same operations, tacitly structuralists and deconstructionists? I'm not sure. Another reaction I have is the inclination to cavil at the incoherence of these images: Steiner relays stripping to dissection, but isn't dissection less a stripping and more a cutting up or cutting into? What about the follow-on from dissection, namely smashing a shell? If one thinks of an eggshell, isn't the point to extract the yolk, rather than 'strip' vital layers? Code-breaking: can that really be compared to an act of surgical dissection? Codebreaking suggests finding the key-it's hardly the same thing as shell-smashing, layer-stripping, or extraction and mining. 
In any case, Steiner's proposition is that the first operation of translation proper is violent insofar as it seeks to possess texts and appropriate their linguistic contents. But Steiner leaves us in a quandary: his claim for translation's aggression is justified by reference to Hegel, Heidegger, and, in a footnote, to Ricœur. Consider: "The postulate that all cognition is aggressive, that every proposition is an inroad on the world is, of course, Hegelian" (Steiner 1975/1992: 313). Heidegger "focuses our attention on understanding as an act, on the access, inherently appropriative and therefore violent, of Erkenntnis to Dasein" (ibid.: 313). Moreover, "it is Heidegger's contribution to have shown that understanding, recognition, interpretation are a compacted, unavoidable mode of attack" (ibid.: 313). The quandary is this: ought one seriously follow up on these philosophical invocations, or else regard them as empty philosophical flourishes, allusions that are merely tendentious?

If one does pursue Steiner's references, one might be tempted to cavil once more: "making inroads" isn't particularly well calibrated to the idea that "cognition is aggressive". "Making inroads" doesn't clarify the degree of aggression at issue. As for Heidegger, we do find him saying, in Being and Time, that "the existential analytic constantly has the character of doing violence" (Heidegger 1996: 288). But such violence is requisite because without it there is no access to a better thought of Being as it withdraws, slips away or remains indistinctly profiled given the accumulation of metaphysical thoughts which must now be dismantled. This violence can also be called (especially in the later Heidegger) 'Destruktion', and characterised in terms of 'Abbauen'. This violence informs Heidegger's desire to recover, or retrieve a truer meaning of Being and of 'Dasein'. It's warranted only because there is a bid for such recovery, and moreover only on the grounds that something-namely Being - can be characterised as self-concealing. Can any of this be meaningfully brought into the vicinity of translation? If one takes up Steiner's footnote, which refers to "Existence and Hermeneutics" in Ricœur's The Conflict of Interpretations, one will be puzzled. For Ricœur's existential analysis does deploy the notion of 'appropriation'-he says, for instance, that 'by understanding ourselves 
[...], we appropriate to ourselves the meaning of our desire to be or of our effort to exist" (Ricœur 1974: 21), but there's no explicit thematisation of appropriative violence.

It's difficult to connect the existential analyses of Ricœur and Heidegger to the ways in which interpreters and translators 'appropriate' literary texts. If one persists with Ricœur, moreover, there is a way to contest Steiner's proposition that appropriation is inherently violent. For in the essay "Appropriation", Ricœur elaborates upon Gadamer's account of 'play' in connection with artworks. Discussing “"play' as the mode of being of appropriation” (Ricœur 1991: 90), Ricœur describes novels offering fictional worlds into which readers might plunge: "worlds are proposed in the mode of play" (Ricœur 1991: 91). He furthermore speaks of authors and readers as playful figures. As for the reader in particular, "appropriation will thus appear as the 'playful' transposition of the text, and play itself will appear as the modality appropriate to the reader $p o-$ tentialis" (Ricœur 1991: 87). Transposition is a better word than any aggressive-sounding hermeneutic possession of the text, and if one remains queasy about Steiner's vision of penetrative incursions into texts, Ricœur says of the reader's appropriation of the text that it's a give-and-take where what the reader playfully receives from what the text playfully offers is nothing less than a new self: "It is always a question of entering into an alien work, of divesting oneself of the earlier ' $m e$ ' in order to receive, as in play, the self conferred by the work itself' (Ricœur 1991: 94). I divest myself of my 'me' and receive a new self: "Relinquishment is a fundamental moment of appropriation and distinguishes it from any form of 'taking possession"” (Ricœur 1991: 95).

In view of Ricœur's account of appropriation, one would hasten to make three remarks. Firstly, Ricœur's reader isn't a translator: what an 'alien' work offers a translator isn't a fictional world, or a new self, but linguistic riches, and it's these riches that are being aggressively possessed. So there can be no talk of 'play' here. Secondly, when Ricœur envisions interpretive activity as entries into, and receptions of 'worlds' (given in the modality of 'as if'), then this describes imaginative projection, describes hermeneutic mediation 
between texts and readers. But that arguably floats too conveniently free of any account of the activity of reading, or the activity of translation. Accounts of mediation, that is, don't describe the active, and aggressive labour of translation (and/as/or reading). Thirdly, when Ricœur discusses Gadamer's term for appropriation ('Aneignung'), he observes that it "means to make one's own that was initially 'alien'. According to the intention of the word, the aim of all hermeneutics is to struggle against cultural distance and historical alienation. Interpretation brings together, equalises, renders contemporary and similar" (Ricœur 1991: 89). But a text about to be translated by Steiner's aggressor might querulously ask whether translation-or interpretation for that matter- "brings together" and "equalises". Even if it does, should such equality imply the achievement of contemporaneity but also that of similarity? Might a text wish to remain unequalised, dissimilar, alien and 'other'? Might it wish to resist the violence of the hermeneutic bid to "make one's own", resist the possessive proclivities of a hermeneutics that cannot (Levinas might observe, and perhaps Steiner too) let the other remain other, cannot think the dilemma of a text seeking to elude the domination of the Same and the Similar?

But if one always lets the foreign text remain wholly other, we would never read anything at all, for fear of falling foul of Levinas's ethical strictures (or we would have to construe an ethics of translation in terms of a 'letting' beyond all interpretive passivities). Appropriation and possession must therefore be risked. Steiner can accordingly reiterate his point: once we speak of appropriation and possession, then there is hermeneutic violence. Still, perhaps there are other, less aggressive options, and we can choose those instead. Gadamer envisages hermeneutic activity as tactful dialogue. Ricœur favors play. But perhaps that's too easy-can one simply opt like this? Perhaps these blandly diplomatic hermeneutic models actively elide the violence that is apparently inherent to cognition, recognition, understanding, interpretation, reading, and translation.

What remains pressingly on the agenda of discussion, therefore, and in any case, is what to do with Steiner's violent imagery. When the focus is on "the appropriative rapture of the translator" 
(Steiner 1975/1992: 316), on "violent transport" (ibid.) and "appropriative penetration" (ibid.: 314), some will think of genderbased violence, and quickly shift from thoughts concerning a mining excavator hauling away the spoils to thoughts of the female spoils of war-Andromache, je pense à vous! My students at Barnard (an all-women's college affiliated to Columbia University) invariably focus on what they regard as unpleasantly 'masculinist' depictions of translatory violence-one student observed that Steiner sounds 'rapey'. Not that women translators don't avail themselves of violent imagery. Consider Rosemarie Waldrop: when translating Edmond Jabès, she felt "envy and pleasure in destruction" (Waldrop 2002: 23). Moreover:

Destruction is unavoidable. Sound, sense, form, reference will never again stand in the same relation to each other. I have to break apart this 'seemingly natural fusion' of elements, melt it down [...]. In this state, the translator will be able, with a mix of imagination and understanding, to penetrate into the work and re-create it. (Waldrop 2002: 23)

She also acknowledges that "there is pleasure in the destruction because it makes the work mine" (Waldrop 2002: 23). Waldrop's destruction is a melting-down, Steiner's is a strip-mining operation. Each to his or her own metaphors for translation's violent activity, I suppose. My own reaction to Steiner's imagery is determined, or over-determined by the fact of my being Irish. My eye is drawn to Steiner's quotation from Saint Jerome: "[The translator] has carried meaning over into his own language, just like prisoners, by right of conquest" (Steiner 1975/1992: 281). What "right" is this? Does the translator's might make right? Not all conquests imply the particular aggressions of colonialism, but I personally think of the Irish situation, and to think along those lines is to end up with Seamus Heaney discussing his Beowulf. Heaney explains that his approach was informed by a metaphor, one which,

is based upon the Viking relationship with the island of Ireland and the island of Britain. There was a historical period known as the Raids and then there was a period known as the Settlements. Now, a very good motive for translation is the Raid. You go in - it is the Lowell method-and you raid Italian, you raid German, you raid Greek, and you end up with booty that you call Imitations. Then there is the Settlement approach: you enter an oeuvre, 
colonise it, take it over - but you stay with it, and you change it and it changes you a little bit. (Heaney 2000: 1) ${ }^{1}$

"Raid" and "booty": this echoes Steiner to an appreciable extent. But Heaney's metaphors are informed by Ireland's violent history, rather than warranted by what Steiner regards as the inevitability of cognitive violence. Yet Heaney adverts not to later episodes of plantation by the English and Scots, but to the Viking raids and visitations - the focus of the poems collected in North. Consider the raid: a raid elicits "booty", and, having acquired such linguistic plunder, one carries the booty away - carries it off and elsewhere to where translations are 'imitations'. Imitations, however, inevitably reveal the original text's own dislocation, the original's outof-placeness, so to speak. But translation-as-settlement doesn't enact that taking away or carting off. The translator assimilates and stays. Yet this settlement is hardly, at least initially, a peaceable concord between host and welcome invitee. The integrative violence of translation-as-settlement is a violence. You colonise the original text. Perhaps, to borrow from Derrida, there's an "essential coloniality" (Derrida 1998: 24) to this kind of translation, whatever benign or malign scenarios one can discern in that ambiguous term 'settlement', whatever necessary parsings one undertakes in respect of 'colonising' and 'colonialisation'. But if settlement means assimilation, that doesn't imply total absorption: Heaney's relation to Beowulf entails changes on both sides. Settlement enjoins both parties to adjustment, and, as regards Beomulf, that results in a subtle, but pointed turning of the tables in view of that English text. It's too much to say that the colonised becomes the coloniser, but there are moments of de-familiarisation where Northern Irish words are imported into Beownlf_-words that, for English readers, feel strange, but for a Northern Irishman like myself, words that induce a feeling of homeliness. In any case, this reformulation of the colonial trope (translation-as-colonisation/colonialisation) in terms of 'settlement' is only possible since Heaney and Beowulf share the same, al-

1 I am grateful for a productive conversation regarding this passage with Mohamed Saki, specialist of translation studies at the Université de Brest. 
beit differentiated language_-English. 'Raiding' involves the encounter with foreign languages-Italian, German, Greek. Imitation-as-raid would thus be inevitable if the transfer involves foreign languages, but translation-as-settlement involves transfers occurring between linguistic shadings that partake of the same English monolingualism. The monolingualism of the other, to be sure, one which can bear the threatening face of English colonial and linguistic hegemony, but one which also carries the sediments of languages other to English, like the Viking parlances Heaney re-articulates in North.

In view of Steiner's imagery, I contemplate Heaney, not Heidegger. For a poet as aware of Ireland's history as Heaney is, the violence of that history will inevitably have occurred to him as he was thinking about different metaphors for translation. It's not a matter of engaging with the probably fruitless discussion as to whether Heaney, because of that history, is entitled to use violent metaphors for translation. It's simply a matter of suggesting that one can consider the translatory 'violence' at issue in different ways- though I claim no primacy for the kind of violence I have in mind. At any rate, Heaney, for me, puts into relief Jerome's prisoner-taking 'right' of translatory conquest - a view of translation's arrogant 'might' Steiner might have considered more thoroughly.

One feels, in any case, inclined to ask Steiner what the text might do, faced with such incursive and extractive penetrations. Imagine the defensive postures of the original text, as if it cringes into prickly self-containment, or retreats into idiomatic untranslatability, refuses thereby to play passive 'host' to the invasive translator. Imagine the text thwarting the hermeneutic overcoming of distance, which - to splice Steiner with Ricœur-enters texts into the 'violent' hermeneutic circle of rapprochement, proximation, propriaton and appropriation. Might it ask hermeneutics to resile from such Entfernung - that de-distancing of the distance between readers, translators and the 'alien' text? Hermeneutics, from Heidegger to Gadamer and Ricœur, privileges the near, regards distance as that which must be overcome. Steiner speaks of strangers becoming guests at the meeting-place of the limen. A counter-hermeneutics 
might speculate on the legitimacy of missing those rendezvous of 'translation', on giving translators the slip, on texts distancing themselves, standing infinitely apart from translation. And while translators begin with trust, shouldn't they begin differently-start by forewarning their texts of the suffering and violence to come? Moreover, Steiner's violence is one-sided-texts are despoiled, scarred like strip-mined ore-seams lying at a landscape's surface. Steiner doesn't envisage violence as a two-way street. Yet recall Venuti's 'foreignisation': the language of the original forces the translator's language to alter and become foreign to itself. Will that have been a certain violence, wrought on the translator in the manner of a linguistic de- or ex-propriation? That is: techniques of settlement and domestication have failed, translation's appropriating and commandeering operations have faltered, and so foreignness remains, like scars on the landscape of the translation.

\section{Translation, or: Eating Well}

"The third movement is incorporative, in the strong sense of the word" (Steiner 1975/1992: 314). Savour, or be irked by this instance of Steinerese - the reader enjoined to the "strong sense" but left unclear as to how strong that strong sense is supposed to be. Would the strong sense of "incorporative" mean that translators (re)embody their texts? But how are they introjected into their bodies? Do translators eat texts? Or is incorporation a metaphor, albeit one we should take as strongly as we can (while resisting the temptation of literal-mindedness)? But what's the strong sense of any metaphor? Steiner: "Comprehension, as its etymology shows, 'comprehends' not only cognitively but by encirclement and ingestion” (ibid.: 314). Comprehension's etymology gives us an idea of prehensile grasping, but there's no etymological relay towards "ingestion". Yet consuming texts, ingesting and assimilating them in the movement of incorporation are apparently the activities at issue. After that penetrative raid on the text, the translator now has to ingest and digest what she has extracted from the text. Translation as 'eating': that's what we must now consider. 
Gustatory metaphors for translation are common enough. Consider Ben Jonson's image: the translator must "draw forth out of the best and choicest flowers, with the bee, and turn all into honey" (Steiner 1975/1992: 269). Steiner comments on this pleasant image of the translator browsing among foreign texts and converting their succulence into honey thus: "For Jonson creative ingestion is the very path of letters" (ibid.). Besides this melittological scenario of creative ingestion, the problems proliferate however, once Steiner's metaphorics of consumption is taken into full account. For if Steiner is right to characterise his account of translation as hermeneutical, relying on the notion that hermeneutics appropriates texts, then we might wonder whether hermeneutics as such is analogous to activities of eating, consuming, and incorporation-in the strong sense of the word. That plunges us into treacherous philosophical waters, however. Matters become more treacherous if we wonder whether all philosophy grounds (though that's probably the wrong word) its discourse by making metaphorical appeals to one or other of the five primary senses_-vision, touch, smell, hearing, taste.

Mindful of the dangers, I nevertheless want to put down several markers-via Derrida. Consider "Economimesis", which addresses Kant's third Critique: at issue, for Kant, is ensuring that aesthetic 'taste' is divorced from any literal-minded associations with gustatory activities. Whence Kant's insistence on hearing songs: hearing isn't eating, and songs give nothing to be consumed. 'It is a question of singing and hearing, of unconsummated voice or ideal consummation", Derrida writes, as opposed to "a consuming orality which as such, as an interested taste or an actual tasting, can have nothing to do with pure taste" (Derrida 1981: 16). But, for Kant, "The greatest nobility accrues to sight which achieves the greatest remove from touch, allows itself to be less affected by the object. In this sense, the beautiful has an essential relation with vision insofar as it consumes less" (ibid.: 19). This also orients us to philosophy's attitude to 'theory' (it connotes the visual): Kant is keen to "[suspend] consumption on behalf of the theorein" (ibid.: 19). Moreover, if ontology's portraits of the self-present subject involve hearing-oneself-speak (hearing oneself speak the cogito, for example), 
then we still have a 'mouth' to contend with, since speaking involves lip-movement. So we can still consider what passes into the body via that mouth:

Hearing-oneself-speak, insofar as it also passes through a certain mouth, transforms everything into auto-affection, assimilates everything to itself by idealising it within interiority, masters everything by mourning its passing, refusing to touch it, to digest it naturally. (Derrida 1981: 20)

Whatever enters the body is subject to an idealising interiorisation, wholly unlike natural digestion. Note mourning: an idealising interiorisation perhaps akin to the mourning ritual that is the Christian Mass and the Eucharistic 'Take this and eat it, do this in memory of me'. Derrida then troubles the idealising activities of an eatingthat-eats-nothing by inspecting Kant's claim that what cannot be assimilated by an aesthetics devoted to the beautiful (and the sublime) is the disgusting. What is disgusting triggers the gag-reflex: we vomit. Disgustingly emetic is whatever cannot be digested, consumed, or incorporated. Thus vomit shadows the boundaries of the entire Critique, and "vomit lends its form to this whole system" (Derrida 1981: 21).

So much for Kant. Consider Hegel, and Derrida's Margins of Philosophy. As in Kant, the association between vision and theory is important:

Sight is an ideal sense, more ideal, by definition and as its name indicates, than touch or taste. One can also say that sight gives its sense to theory. It suspends desire, lets things be, reserves or forbids their consummation. The visible has in common with the sign, Hegel tells us, that it cannot be eaten. (Derrida 1982: 92)

As for hearing, Derrida cites Hegel's Aesthetics: it's “one of the most theoretical and not practical senses, and it is still more ideal than sight. For the peaceful and undesiring (begierdlose) contemplation of works of art lets them remain in peace and independently as they are, and there is no wish to consume or destroy them" (Derrida 1982: 92). Hearing and sight are favoured because there's no physical contact with artworks - they accordingly remain in-tact, independent, immune from threats of desirous consumption. 
As for hermeneutics, Derrida is startlingly blunt. In an interview, having spoken of figures of incorporation, cannibalistic tropes, Hegel, and the mystical eating of the Eucharistic sacrament, Derrida remarks:

Little wonder that Gadamer's philosophy is so marked by terms taken from digestion, that he is such a gluttonous thinker. His hermeneutics is, after all, precisely about assimilating that which is foreign. What is radically alien in the other doesn't have a chance-it will be digested, melted down in the great tradition, wolfed down mercilessly. (Derrida 2009: n. p.)

This claim is echoed by John Caputo. Hermeneutics, Caputo declares, "is a philosophy of digestion which is always interested in assimilating the other, making it part of its substance" (Caputo 1988: 67).

A defense of Gadamer might be mounted by invoking Ricœur's essay “Appropriation”. Instead, though, let's simply say "Derrida, tu quoque!" For Derrida also has scenes of eating-particularly frequent, moreover, when he engages with translation. Take "Che cos'è la poesia?" Answering the question 'What is poetry?' (and responding to the Italian question in translation), Derrida imagines a hedgehog stranded on a road — a lorry rumbles towards it. That mortal peril is likened to the peril of $a$ poem threatened by genericity - being folded into the designation that awaits all poems, namely poiesis. The hedgehog can't avoid being run over; a poem can't avoid generic subsumption. Yet the hedgehog-poem appeals for translation, asks for that 'afterlife' described by Benjamin. Another survival strategy desired by the poem is that it be learnt by heart-become part of mourning rituals that ensure the living-on of something dead, insofar as that past life is now borne in the mourner's memory. But whatever of the poem that can be taken to heart, it cannot be its exterior, material support-its letters, scored on a paper page. So the poem says "Destroy me, or rather render my support invisible to the outside [...]. Eat, drink, swallow my letter, carry it, transport it in you, like the law of a writing become your body: writing in (it)self' (Derrida 1995: 293). Here is transportation or translation as an ingestion of the poem that relocates it to the site of memory and its privileged organ - the heart. The letter 
is a hedgehog's quill. Swallowed, it pricks the heart with the pang of memory and inscribes itself on the heart: writing inside the self, the writ of a law commanding Derrida to remember.

Such is Derrida's Aesopian fable of translation and transportation. But there's another text where ingestion induces an impulse to throw up. Igel, incidentally, is hedgehog in German. By some guttural relay, from German to French, we might end up having to pronounce Hegel's name in French-ehgl. So to Glas, and the first line: "what, after all, of the remain(s), today, for us, here, now, of a Hegel?" (Derrida 1990: 1) What remains to be digested, or vomited, of Hegel? ' $G$ l, which resounds frequently in Glas, is the glottal sound of gagging. What remains undigested, unsublated by the voracities of Hegel's dialectic? Derrida tries to find out by forcing Hegel into having a conversation in French, and by forcing him into a dialogue no dialectical foresight could have anticipated-a dialogue with Jean Genet. Philosophy translated into literature: what remains of Hegel after that translation is a philosophical colossus rendered as an almost pornographic monstrosity.

Let's now braid Steiner's way with eating and consuming with Derrida's and consider occasions when ingesting foreign texts consumes translators - as if they're gobbled up by the texts, rather than vice versa: "The dialectic of embodiment entails the possibility that we may be consumed" (Steiner 1975/1992: 315). Perhaps the 'dialectic' of embodiment involves the translator taking the text into her own body but unfortunately the parasite takes over the hostthe translator eaten from within. Steiner imagines translators choking on texts they have inhaled: "Writers have ceased from translation, sometimes too late, because the inhaled voice of the foreign text had come to choke their own" (ibid.: 315f.). A translator should learn when to gag, for fear of being choked. These menaces_-being consumed, choking - also menace cultures hosting imported foreign texts. Threatened especially are debilitated cultures unable to withstand the impact of overwhelming translations: "Societies with ancient but eroded epistemologies of ritual and symbol can be knocked off balance and made to lose belief in their own identity under the voracious impact or premature or indi- 
gestible assimilation" (ibid.: 316). Another circumstance of indigestion occurs when difficulties in assimilating translations trigger a reaction in the host culture to get them out of the system: "After a time, the native organism will react, endeavouring to neutralise or expel the foreign body. Much of European romanticism can be seen as a riposte to this sort of infection" (ibid.: 315). Described here is romanticism expelling the facile classicism of the French $18^{\text {th }}$ century.

Steiner's metaphors thoroughly elaborate scenarios of translation and eating, indigestion and the body's response to a glut of foreignness. But consumption apparently comports with infection. Consider: 'neutralise' perhaps implies a body's immune response - antibodies reducing the threat of disease. Here, the disease is a contagion of facile imitations. Host cultures must prepare for translation's importations otherwise they will react to such imports by producing derivative pastiche. I imagine it as a case where a host culture suffers a bout of 'bad mimesis' - the virus of mere mimicry. Or, as Steiner says, "There can be contagions of facility triggered by the antique or foreign import" (Steiner 1975/1992: 315). Consider, now, the following: "No language, no traditional symbolic set or cultural ensemble imports without risk of being transformed. Here two families of metaphor, probably related, offer themselves, that of sacramental intake or incarnation and that of infection" (ibid.). Indeed, Derrida might say, these two metaphorical families are "probably related".

To approach that 'probable' relation between sacramental intake and infection, let's firstly say this: you must know that what you're eating-literally, or in terms of an idealising interiorisation -is good for you. You must ascertain that what is taken into the body, hosted therein, incorporated and incarnated as your own body (the translator's body, or the body of culture at large), is nutritious food, and not a poison-one which the body's immune system will otherwise seek to neutralise or expel. The worst situation is a culture contracting an autoimmune disorder, where too much translation, appropriation, incorporation or incarnation induces the hosting body to turn on itself, killing thereby the good of 
translation along with the bad (facile mimicry), as if the cultural antibodies can no longer tell the difference.

Philosophical scenarios of not being able to tell the difference are Derrida's speciality. Consider the pharmakon - poison or cure? Do translations cure or at least enliven host cultures, or do they poison them with the virus of 'bad mimesis'? But pharmakon means both poison and cure, and hence matters become acutely difficult, if not undecidable. We know this from Derrida's discussion of Platonic mimesis, and we can now push the point upon Jonson (and Dryden), on Lowell, as well as on Steiner speaking of the contagion of "facility". How to decide whether translation's imitation is good mimesis or bad? How to decide whether translation partakes of the general logic (or various translations) of mimesis, and when to separate the practice of translation from that of representing in general, or representation as such? 'The 'economimetic' focus of Derrida's text on Kant pushes the matter up to the verge of the Derrida essay I want to now invoke. For while it's no accident that mimesis links to economy ('economy' will return in Steiner's fourth motion, inevitably), the point for now is that translators working on behalf of host cultures must do their receptive, assimilative, and mimetic work informed by a knowledge sapient enough to know when to expel, or reject foreign imports, or-to put it in the queasy terms Derrida forces on us - when to vomit and gag.

One must know how to eat well. So for translators, so for hermeneutics - gluttonously zealous in its appropriations and assimilations. The Derrida essay I'm alluding to is "Eating Well" where he discusses ingestion, incorporation, and introjection. Translation: or, 'Eating Well'. Eating well, Derrida observes, supposes a good diet, but also an eating where 'good' bespeaks an ethical value. "How, for goodness' sake, should one eat welp?" (Derrida 1995: 282) “'One must eat well' does not mean above all taking in and grasping in itself, but learning and giving to eat, learning-to-givethe-other-to-eat. One never eats entirely on one's own: this constitutes the rule underlying the statement 'one must eat well'. It is a rule offering infinite hospitality" (ibid.). This routes us back to Real Presences: picture that act of hospitality as sharing a meal—commen- 
sality. Then again, one still must ensure that "infinite hospitality" doesn't entail the risk that host cultures are consumed by the translations they incorporate, inhale, and purport to ingest.

In any case, these 'ethical' scenarios return us to the hermeneutics of assimilation and the Levinasian model of the I vis-à-vis the other: here, eating well would mean not consuming the other. Yet, recall Derrida's “Economimesis": "Hearing-oneself-speak, insofar as it passes through a certain mouth [...] assimilates everything to itself by idealising it within interiority, masters everything by mourning its passing, refusing to touch it, to digest it naturally." Compare "Eating Well":

in experience (I am speaking here of metonymical 'eating' as well as the very concept of experience), one must begin to identify with the other, who is to be assimilated, interiorised, understood ideally [...], speak to him or her in words that also pass through the mouth, the ear, and sight. (Derrida 1995: 283)

At issue are the bodily portals through which the other is incorporated, in the strong sense of the word, as sounds for the self to hear (as itself), as insights for the self to see, as tastes (for instance, aesthetic tastes) to have. Eating well is an assimilation of the other justified ethically only if interiorisation is ideal, or idealising. Arguably the supreme illustration of this idealising interiorisation, this 'eating', is the Eucharistic sacrament-Steiner's "sacramental intake or incarnation". An eating justified only if the aim is to enact a mourning ritual. Derrida's hedgehog would like to participate in this: it effectively says 'Eat and drink me, do this in order to mourn my passing. Do this in memory of me'. For me, Steiner's metaphorics of eating and consumption all converge on the Eucharistic scene. That's the Host here. It converges like this because Steiner wishes the meeting of reader and text, of translator and text, to resemble a religious sacrament. And if it therefore comes down to this "intake", as if works of high literature are effectively transsubstantiated during the ritualistic ingestion, then the reader or translator would now commingle and commune with realpresence. Incorporation, in the strongest sense of the word, would incarnate texts as real presences.

Is this ridiculous? James Wood cites Real Presences: 
Where we read truly, where the experience is to be that of meaning, we do so as if the text [...] incarnates (the notion is grounded in the sacramental) $a$ realpresence of significant being. This real Presence, as in an icon, as in the enacted metaphor of the sacramental bread and wine, is finally irreducible to any other formal articulate. (Wood 1999: 160)

Note how "as if' infiltrates itself into what otherwise is reading truly characterised as an encounter with real presence. What is an "enacted metaphor"? As Woods objects, discussing Steiner's account of real presence, Steiner "thinks it is frankly theological; it is, alas, vaguely religious” (Wood 1999: 160). For Wood, “incarnation' is not a word that should be used lightly" (ibid.: 163), not because it's blasphemous, but because, in Steiner's hands, the word is meaningless: "Steiner is simply a metaphorical critic who imagines himself to be a theological one" (ibid.: 163). Indeed. Steiner asks us to take incorporation in the strong sense of the word, and imagine translatory ingestion as "sacramental intake and incarnation" and either "enact" metaphors, or forget that they are metaphors. Not that the temptation to idealise consumption is exclusive to metaphorical literary critics - it's also common, Derrida would observe, in philosophers. Whence Kant. Whence Derrida himself. In any case, perhaps Steiner reads and communes with real presences, experiencing "the numinous intimations which relate hospitality to religious feeling". But do the rest of us?

\section{The Senses of Translation}

We should probably desist from such metaphorising. Nevertheless, if we're to seriously (or unseriously) entertain these analogies for translation's activities, then it's still worth attending to the ways translation 'theory' has deployed one or other of the five senses. If there's something ethical at stake, moreover, because translation is violent, then recall Hegel: sight gives its sense to theory, suspends desire and forbids consummation. Hearing artworks prompts "no wish to consume or destroy them". Better that we base our theories on vision and hearing, and touch not. It's better to implement 'theoretical senses' and avoid 'practical senses' lest textual contact trig- 
ger consuming desire. If the problem is Begierde, translators must ensure that the textual embrace not involve a graspingly aggressive touch - be mindful of what Steiner describes as "the cognate acts of erotic and of intellectual possession" (Steiner 1975/1992: 314). Note the calamitously question-begging word "cognate". If we dare touch the text, it would preferably involve Steiner's "tact of heart" and Gadamer's dialogical tact-touches-that-don't-touch. Or else what Benjamin imagines: "A translation touches the original lightly and only at the infinitely small point of the sense" (Benjamin 1923/1996: 261).

The two senses Steiner especially deploys are hearing and vision. Translation as the original's echo: sometimes, Steiner says, "there can be no doubt that echo enriches" (Steiner 1975/1992: 317). Hegel would approve-echo 'hears' the text, but doesn't touch it. Translation responds to the original's call, and perhaps"enriches" suggests this- the echo supplies more than a mere answering reproduction of that original. Recall Narcissus and Echo. Imagine Echo feigning to repeat the last syllables of Narcissus's utterance in order to say something more, or different-as if her response, like translation's response, would be more than reiteration even as translation's echo responds to the original that initiates, by its call, the acoustical interaction between itself and the translation. (Benjamin said that translation has no muse-might I suggest Echo?) Narcissus beholds his image in a pool. Now we can broach the sense of sight. Here, more fully, is Steiner:

But there can be no doubt that echo enriches, that it is more than shadow and inert simulacrum. We are back at the problem of the mirror which not only reflects but also generates light. The original text gains from the orders of diverse relationship and distance established between itself and the translations. The reciprocity is dialectic: new 'formats' of significance are initiated by distance and by contiguity. Some translations edge us away from the canvas, others bring us up close. (Steiner 1975/1992: 317)

Was Echo ever more than the shadow of Narcissus's reflection as he looked into that pool-mirror? Can translation's echo offer "more" than inert simulacrum? Is translation a mirror (the mimetic mirror) or something more than that? "We are back at the problem of the mirror which not only reflects but also generates light". Why? 
Recall M. H. Abrams: the mirror suggests pre-Romantic practices of mimesis, but Romanticism replaced the mimetic mirror by a lamp because Romanticism privileged genius-the light-source which originates, and hence never imitates. The Romantic image is that of radiance, not reflection. Steiner has mirror and lamp: translation not only reflects light but also generates its own light. As if, likewise, Echo is not only a paltry duplicate of Narcissus's utterance, but also her own voice, capable of adding more to her response.

Translation: the mirror and the lamp. But can translation be a species of mimesis (whence mirror), and yet refuse specularity in the name of a lamp-lit, light-generating radiance that illustrates the independence of translation when it doesn't simply obey the order of mimesis - to come second to the original, like Echo comes second to Narcissus? "The original text gains from the orders of diverse relationship and distance established between itself and the translation". But how does the original gain by such distance? "The reciprocity is dialectic: new 'formats' of significance are initiated by distance and by contiguity. Some translations edge us away from the canvas, others bring us up close." A pity Steiner doesn't measure those distances and contiguities for us. Important, though, is that "reciprocity" is characterised as "dialectic". Yet is dialectic an implementation of reciprocity, or does it sublate such reciprocities and the va-et-vient between translation and original? Perhaps dialectics devolves some of its operations to non-dialectical activities of translatory mimesis-mirroring, providing screens and canvases, etc. Perhaps dialectics relieves translation of its mimetic tasks, albeit in a moment of relève (to use Derrida's French) that sublates, but doesn't cancel translation's mimetic activities by adducing a lamp so that translations generate their own light, even as they remain the reflected light of the original's glow.

In the second preface to After Babel, Steiner speaks of "what I designate as 'transfiguration'-where the intrinsic weight and radiance of the translation eclipses that of the source" (Steiner 1992: xvi). Imagine the radiance of translations that eclipse the source. Back to the mirror reflecting and generating light: here the shadow cast by translation's effulgent light overshadows the original like a 
dark sun. We are far from Lowell's 'photographic' prose translations. Far, moreover, from Benjamin's image of translation: “A real translation is transparent; it does not cover the original, does not block its light" (Benjamin 1923/1996: 260). Real translations let the originals' light shine through what would otherwise obscure them (this is interfulgence). Steiner has his Benjaminian transparencies too: after a period of translatory work, "the text in the other language has become almost materially thinner, the light seems to pass unhindered through its loosened fibres" (Steiner 1975/1992: 314). Consider that light shining through the loosened weft of the original: the translator's task is to supply the tain to complete the mirror upon which such light is reflected.

Some translations eclipse the original with their bleaching light. But inadequate translations are perhaps more revelatory: "The failings of the translator [...] localise, they project as onto a screen, the resistant vitalities, the opaque centers of specific genius in the original" (Steiner 1975/1992: 317). Translators often suffer from the parallax view: a dark stain mottles what Ezra Pound called the translator's 'canvas' and that darkness paradoxically irradiates the original's specific genius. Translators are boxed in their own camera obscura: their light rays only halo the light or lamp of genius that so fascinated Romanticism. Translation illumines only in the manner of a reverse mirror, produces only photographic or X-ray negatives. It's perhaps better that way, since too good a translation eclipses genius. Genius mustn't be occulted by shadow, overcast by Nachmachung (Kant) or 'simulacrum' (Steiner). Back to Plato's cave, ye translators. Translation feints and jabs at genial light projected on a cave-wall. Don't mistake the shadow-boxing of translation for realpresence.

\section{Impossible Fidelities of Translation}

Final motion. Translators have taken too much. They must make reparations:

We come home laden, thus again off-balance, having caused disequilibrium throughout the system by taking away from 'the other' and by adding, 
though possibly with ambiguous consequence, to our own. The system is now off-tilt. The hermeneutic act must compensate. If it is to be authentic, it must mediate into exchange and restored parity. (Steiner 1975/1992: 316)

"Possibly with ambiguous consequence". How vague that is. Steiner continues: "The enactment of reciprocity in order to restore balance is the crux of the métier and morals of translation" (Steiner 1975/1992: 316). But how might translators 'enact' that reciprocity, and therefore fulfill the moral obligation presiding over their activities? Is the achievement of 'parity' the same as the fulfillment of 'fidelity"? For Steiner, "all theories of translation-formal, pragmatic, chronological — are only variants of a single, inescapable question. In what ways can or ought fidelity to be achieved?" (Steiner 1975/1992: 275). Moreover,

[t]he translator, the exegetist, the reader is faithful to his text, makes his response responsible, only when he endeavours to restore the balance of forces, of integral presence, which his appropriative comprehension has disrupted. Fidelity is ethical, but also, in the full sense, economic. By virtue of tact, and tact intensified is moral vision, the translator-interpreter creates a condition of significant exchange. (Steiner 1975/1992: 318)

"Integral presence": restoration would ideally imply that a translation presents the original as an 'integral' whole, as if translating achieves a bringing-back-to-presence, renders the original wholly, integrally, and really present-to-itself. But the reality is that translation restores the original to presence only insofar as it returns as a re-presentation, copy, substitute, or imitation of that original now permanently in absentia. Steiner claims that fidelity is ethical, but also economic in the full sense. What full sense is this? Consider two quotations: "There is, ideally, exchange without loss" (Steiner 1975/ 1992: 318-9). And, quoting Pierre-Daniel Huet, "[h] is one study is faithfully to display his author whole, taking nothing away and adding nothing" (Steiner 1975/1992: 278). "Display"__an interesting term. But if one takes nothing, is that a taking? If one adds nothing, is that an adding? Steiner invokes Lévi-Strauss:

The general model here is that of Lévi-Strauss's Anthropologie Structurale which regards social structures as attempts at dynamic equilibrium achieved through an exchange of words, women, and material goods. All capture calls for subsequent compensation; utterance solicits response, exogamy and en- 
dogamy are mechanisms of equalising transfer. Within the class of semantic exchanges, translation is again the most graphic, the most radically equitable. [...]. A translation is, more than figuratively, an act of double-entry; both formally and morally, the books must balance. (Steiner 1975/1992: 319)

Questions galore. Would translation be radically equitable if it never participated in economic exchange, in the manner envisaged by Huet? How is translation more than figuratively an act of double-entry book-keeping? Morally: is this the probity of insurance agents paying out compensation for the original's loss in translation? Capture calls for subsequent compensation: remember Jerome's translator transporting meaning "just like prisoners, by right of conquest". Does that "right" supersede, or nullify laws requiring translators to compensate original texts for the "prisoners" (or Lévi-Strauss' women) captured and carted off? Difficult to imagine capturers returning their captives. If capture calls for compensation, is that a matter of paying an only symbolically equivalent amount for what one still intends to keep?

These questions wouldn't obtain if translation achieved Huet's ideal-took nothing from originals so as to leave them whole (a leaving that would never have been a taking). But since translations do take something from texts-just like prisoners, as an activity of 'capture', then how does translation give back what has already been taken? Can one take with one hand, and give back with the other? I think not: the restitution can only be symbolic. Whence Derrida, in 'What is a 'Relevant' Translation?", arranging his scene of translatory parity and exchange via The Merchant of $V$ enice and the famous pound of flesh:

In The Merchant of Venice, as in every translation, there is also, at the very heart of the obligation and the debt, an incalculable equivalence, an impossible but incessantly alleged correspondence between the pound of flesh and money, a required but impractical translation between the unique literalness of a proper body and the arbitrariness of a general, monetary, or fiduciary sign. (Derrida 2013: 361)

Imagine Shylock contemplating Steiner's invocations of 'compensation' and 'exchange': translators are in permanent breach of contract- they never pay back in the form stipulated by the contract, 
offer substitutes for the real thing (monetary signs for real flesh, imitations for realpresences), and hence never discharge their debt.

The problem with scenarios of capture/recompense, debt/ payback, giving/taking is that whatever the translator takes from the original text, something is left behind: "The appropriative 'rapture' of the translator $[. .$.$] leaves the original with a dialectically$ enigmatic residue" (Steiner 1975/1992: 316). What is a "dialectically enigmatic residue"? Wounds, perhaps, attesting to what dialectics violently took away-residual scar tissue surrounding what's now missing from the original. Or is it that "residue" means that something of the original remains behind, untaken, unravished, inviolate and unappropriated? If the latter, how does dialectics leave something behind, un-assimilated and un-amenable to the Aufhebung of a 'relevant' translation? But if something remains, then given Steiner's appeal to equity and parity, one wonders whether such economies of total restoration and reparation are possible-you can only incompletely give back what you only incompletely took in the first place. Something has seemingly escaped the logic of economy, something resists the calculus of translation-as-accounting. I don't know what that residue is, and what translatory 'dialectic' of leaving and taking is involved. It's indeed "enigmatic".

Let's consider matters aneconomic in order to reconsider translation's ethics, and invoke Mauss and Derrida on the 'gift', rather than Lévi-Strauss on 'exchange'. For while economy involves circulation, exchange and return, gifts interrupt economic logics. A gift shouldn't return to the gift-giver. No reciprocity, return or exchange ought occur here. Steiner's first motion, we recall, involves the "radical generosity" of the translator's trust in the text's meaningfulness. But that generosity halts before the second motion, where the violent taking begins. Should translators keep giving, so as never to take? Instead of an "exchange without loss", should they replace that by a gift-giving without exchange?

What to give, though? Consider a comment by Anthony Pym: "In the ethics of alterity, the translator would welcome the foreign text as a person, giving of themselves and respecting otherness, in a way that goes well beyond generalised deontological rules and cal- 
culations" (Pym 2001: 6). Perhaps translation actually begins thanks to prosopopoeia. For welcoming to be unconditional, translators must give of themselves and that giving must go well beyondinfinitely beyond-all calculations. Yes: gifts suspend 'economic' calculations-accounting, counting, exchange and compensation. But that donation must also go beyond the calculus that measures parity, and indeed calls that parity fidelity, if it's true that "fidelity is ethical, but also, in the full sense, economic". Such fidelity is calculable, because Steiner associates it to an economics of recompense and equivalence, and indeed models translation's morals on the activities of an accountant balancing the books. Steiner's translator is able to count the cost of what he has done, violently, to the text, and can calculate the amount of compensation his 'capture' calls for. Moreover, since motion 4 makes up for the violence of motion 2 then, besides the difficulties of deciding what kind of violence this is, one can at least say that it's a calculable violence-has a measurable effect, a countable cost.

\section{Echolalia}

Is Steiner a deontologist masquerading as a Levinasian? Deontology needs rules. Rules imply measurement and ratio. Fidelity, for Steiner, is the rule. Fidelity subscribes to deontology if fidelity involves an economy of calibrated costs, prices, and book-balancing. We discern a Derridean/Levinasian ethics of translation only if translators are generous beyond calculation, go beyond all deontologies, and only if texts remain immune, like Huet's depicted 'whole', from the entire business of give-and-take. That's impossible. But no less impossible is the ideal of fidelity. Steiner: "The ideal, never accomplished, is one of total counterpart or re-petition - an asking again which is not, however, a tautology. No such perfect 'double' exists. But the ideal makes explicit the demand for equity in the hermeneutic process" (Steiner 1975/1992: 318). Ethics finds its prescriptive source in the impossibility to which any ideal commands us. Ideals motivate us to do better, to fail better. Translation's ideals: total counterpart, perfect doubling. Translation must operate in the im- 
age of its own impossible ideal of equity and be inspired by it. I imagine texts asking and asking again, petitioning translators that such ideals be realised. Echo, translation's muse, Narcissus's counterpart, is perhaps capable of such re-petition. Alas that Echo's rejoinder communicates the sadness of parting, however. Still, she may yet give back the original text's own call, and, as Heaney puts it in "Personal Helicon", return the original's voice moreover "with a clean new music in it" (Heaney 1966/1991: 44).

\section{References}

ABrams, M.H. (1953): The Mirror and the Lamp. Oxford: Oxford University Press.

BenjAmin, Andrew (1989): Translation and the Nature of Philosophy. New York: Routledge.

BenjAMIN, Walter (1923/1996): Selected Writings. Volume 1: 1913-1926. Eds: Marcus Bullock and Michael W. Jennings. Cambridge: Harvard University Press.

BoOTH, Wayne (1988): The Company We Keep. Berkeley: University of California Press.

CAPUTO, John (1988): “Beyond Aestheticism: Derrida's Responsible Anarchy”. Research in Phenomenology 18, pp. 59-73.

DERRIDA, Jacques (1981): “Economimesis". Trans. by Richard Klein. In: Diacritics $11 / 2$, pp. 2-25.

_ id. (1982): Margins of Philosophy. Trans. by Alan Bass. Chicago: Chicago University Press.

_ id. (1990): Glas. Trans. by John P. Leavey and Richard Rand. Lincoln: Nebraska University Press.

_ _ id. (1995): Points: Interviews, 1974-1994. Ed. by Elisabeth Weber, trans. by Peggy Kamuf and others. Stanford: Stanford University Press.

_ id. (1998): Monolingualism of the Other. Trans. by Patrick Mensah. Stanford: Stanford University Press.

_ id. (2009): "An Interview with Jacques Derrida on the Limits of Digestion”. Daniel Birnbaum and Anders Olsson. In: e-flux 2, n. p.

_ id. (2013): Signature Derrida. Ed. by Jay Williams. Chicago: Chicago University Press.

Heaney, Seamus (2000): Sounding Lines. The Art of Translating Poetry (= Doreen B. Townsend Occasional Papers, Vol. 20). Berkeley: University of California Press.

_ id. (1966/1991): Death of a Naturalist. London: Faber and Faber.

HeIDEGGER, Martin (1996): Being and Time. Trans. by Joan Stambaugh. New York: SUNY Press. 


\section{Brian O'Keeffe}

KEARNEY, Richard (2003): Strangers, Gods and Monsters. New York: Routledge.

PYM, Anthony (2001): “The Return to Ethics in Translation Studies”. In: The Translator 7, pp. 129-138.

Riceur, Paul (1974): The Conflict of Interpretations. Ed. Don Ihde. Evanston: Northwestern University Press.

_ id. (1991): A Riccur Reader. Ed. Mario J. Valdés. Toronto: University of Toronto Press.

STEINER, George (1975/1992): After Babel. New York: Oxford University Press.

_ id. (1989): Real Presences. Chicago: University of Chicago Press.

WALDROP, Rosemarie (2002): Lavish Absence. Recalling and Rereading Edmond Jabès. Middletown: Wesleyan University Press.

WoOD, James (1999): The Broken Estate. London: Pimlico. 